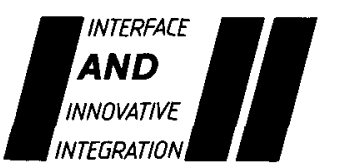

ges
高
速

船

\title{
超細長双胴船型による高速フェリー*
}

\author{
野上 浩**，任々木治夫**，長野健"
}

\section{Fast Ferry by Super Slender Twin Hull*}

by Hiroshi Nogami**, Haruo Sasaki** and Takeshi Nagano***

キーワード：高速船, カーフェリー, 双䏤船, 構造, 加工, 溶接

\section{1. 緒 言}

最近では, 40 ノット以上の速力の高速旅客艇は数 多く就航するようになったが, トラック, 乗用車等 も積載できて 40 ノット程度の速力て航海でる船 は, その実續は非常に限られている。一方, 内海や 㳂岸航路における乗客と乗用車の同時翰送に対する 高速化の要求は顕著なものがあるし, 貨物輸送の分 野においても，海上輸送へのモーダルシフトという 言葉が紙上でもよく取り上げられているごとく，陸 上輸送の限界が話題となっている今, 高速海上輸送 への期待は緊急のものとなってきた。

こうしたニーズに対応するため,「乗り心地の良い 高速フェリー」を目標に, 1987 年より東京大学と共 同で研究開発を進めてきた, 超細長双胴船 (SSTH: Super Slender Twin Hull）に関して一連の基礎研 究を終え，開発設計に見通しをつけることができた。

さらに製品の信頼性を摇るぎないものとするため に, 1991 年 10 月には全長 $30 \mathrm{~m}$ の実験艇を建造・進 水させ，実海域試験を行っだ”。これらの諸試験の データは, 例えば全長約 $92 \mathrm{~m}$ の高速フェリー等の 開発設計にフィードバックされた。

本報告では, 高速フェリーSSTH の開発に関し て, 主として設計, 材料, 施工の面から述べる。

“原稿受付 平成 4 年 8 月 24 日

** 石川島播磨重工業 IshikawajimaHarima Heavy Industories Co., Ltd アイ・エイチ・アイ・アムテック IHI AMTEC Co., Ltd

\section{SSTH のコンセフト}

SSTH は車両等の輸送に最も適している船型と して選択された。その主たる理由として，超細長浮 力型船体は，高速船としては重量物となる車両等を 搭載しても推進馬力の増加が他船型よりかなり小さ いこと、および波浪中の絴摇れの性能の優秀性によ り高い就航率が保持できることをあげることができ る.その SSTH とは競技用ボートのエイトのごとき 極めて細長い船体を二つ並べて連結した，高い経済 性を有する浮力支持型双胴船型である，他の重量支 持方式船型に比べて, 載貨重量が速力性能に与える 影響が小さいことにより，小型船から大型船までさ まざまな市場の要求に応えることが可能である。

\section{3. 高速船の開発における構造の軽量化}

一般的に高速船の開発は，その初期には船型的な 開発がメインであるが，構造の軽量化も開発の重要 なポイントとなる。構造重量を軽くてきれば，必要 主機馬力の低減あるいは積載重量の増加が可能にな る.その一方で，船体構造の限界設計を試みるゅえ に軽量化構造の設計, 工作は十分な検討を行う必要 がある。

\section{SSTH 実酸榳}

\section{1 実験艇建造の背景}

本開発においては，まず理論検討そして水槽実験 による検証と考証を反復しながら，概念設計を終了 させた。しかし，SSTH はまったく新しい概念によ 


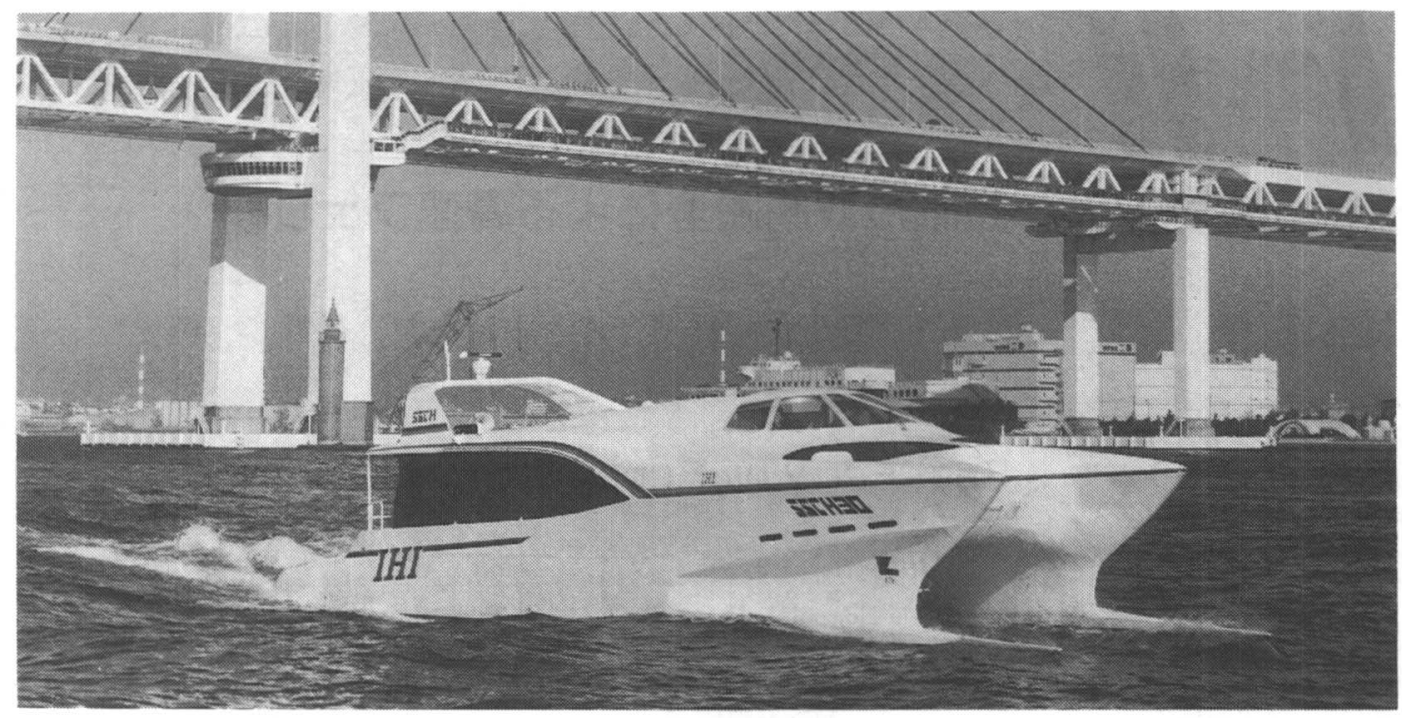

図 1 SSTH 30 航走状態

る高速船であるため, 大型実船の建造の前にかなり の大きさの実験艇を建造し, 実際の海面で実験を行 い, 速力性能, 耐航性能, 操縦性能抢よび構造強度 を含めた総合評価を行い, 実船の設計に反映させる ことにより，製品の信頼性を高めることが必要であ る.

この実験艇の主要目は以下の通りである.

$\begin{array}{ll}\text { 全長 } & 30.4 \mathrm{~m} \\ \text { 幅 } & 5.6 \mathrm{~m} \\ \text { 総トン数 } & \text { 約 } 40 \text { トン } \\ \text { 最大速力 } & 28.2 \text { ノット } \\ \text { 主機関 } & \text { 高速ディーセルー綵 } 440 \\ & \text { 常用 約 } \\ \text { 航続距離 } & \text { 約 } 200 \text { 海里 } \\ \text { 推進装置 } & \text { プロペラ } \\ \text { 船体材質 } & \text { アルミ合金 }\end{array}$

SSTH 実験艇の航走状態を図 1 に示す。

\section{2 実験艇の構造}

高速船は船体重量の軽量化のためアルミニウム合 金を使用することが多く, SSTH 実験艇も主船体・ 上部構造のすべてをアルミニウム合金で建造した.

SSTH は排水量型の高速船であり, 浮力以外の支 持力をもつ高速船や滑走型の高速船とは異り, 構造 強度の検討では通常の排水量型双胴船と基本的に同 様な取扱ができる.SSTH の実験艇の構造設計は, 運輸省の「軽構造船暫定基準」にしたがって行った.

4.2.1 船体構造材料

本船の船体構造は下記の JIS アルミニウム合金を 使用した。 上部構造部には $\pi$ セクションと呼ばれる
大型押出材および船首部の一部にはアルミニウム合 金の鍛造品も使用した.
板材
A5083P-O
型材
A5083S-H112

\subsection{2 船体構造様式}

本船は, 主船体および上部構造とも縌式肋骨方式 を採用し, 縦通材の横肋骨貫通部は一般商船で用い られるスロット構造とせず,まわし溶接のないス リット方式とした，横置隔壁は船首隔壁を含めて左 右舷各々 4 枚, 縦通隔壁は船体中央部 (連結部)に 1 条設置した。 上部船体の横助骨は適当な位置で支柱 に支持されるとした。

\subsection{3 構造強度}

縦強度は, 軽構造船暫定基準に示される縦曲げ モーメントに対して検討した。本船は船長が $30 \mathrm{~m}$ と短いこと, 限定沿海船であることから軽構造船暫 定基準で決定される構造寸法で十分な縦強度を有し ていることを確認した。

双胴船に特有なスプリットフォースやピッチコネ クティングモーメント等の波浪荷重に対しては, 従 来の推定法で荷重を推定し強度確認を行った。これ らの荷重に対しては, 実海域実験において双胴間の 連結部応力を計測し, 解析的な手法で求めた荷重と の比較検討を行うこととした。

SSTH 船型の特長の 1つであるDSB (Double Stair Bow：二段船首形状）および船首連結部船底 については衝撃荷重に対する検討を行い，十分な強 度を有することを確認した。

\section{3 実験艇の工作}




\subsection{1 建造要領}

長さ $30 \mathrm{~m}$ 程度の船を建造する場合は,まず主要内 部骨材で船の骨格を製作し，外板およびパネルを張 り付けて建造するいわゆる建付け法が用いられる が，本船では鋼製大型船で用いられる立体ブロック 建造方式を採用した. 本船のブロック割は鋼船のブ ロック割と同様の思想で行い, 合計 13 プロックで建 造した。

建造に当っては十分剛性のある本船專用架台を製 作し, 製作ブロックの保護および大組み立て時の精 度を確保した。またアルミニウム合金の溶接品質の 確保には万全の注意を払い, 建造のすべてを工場建 屋内において行った。建造の様子を図 2 に示す。進 水作業についてはクレーンを用いた吊揚着水方式を 採用した。

\subsection{2 切 断}

アルミの切断は, 丸ノコ, 帯ノコ, ジグソー等を 用いて手切断を行った. 問題点としては, 切断時の 騒音が大きいことがあげられる。

\subsection{3 曲 げ}

ローラー曲げとプレス曲げに線条加熱法を併用し て曲げ加工した.シリーズ船の場合の三次元曲げに は専用プレスが有効であると考えられる。

\subsection{4 溶接施工}

本船の溶接は, MIG 溶接わよぴ TIG 溶接を併用 し, 船体主構造部の溶接は主として MIG 溶接, 艤装 品の取り付けには主として TIG 溶接を使用した。

本船の双胴間連結部および DSB 部では内側から の溶接が不可能な箇所があり, 栓溶接やチル溶接を
用いた。チルプレートによる立向, 上向溶接, さら に船首骨材は, 一体削り出し部品であり, 栓溶接の 孔加工も含めて溶接品質確保（ブローホール対策） を行った。

\subsection{5 ひずみ取り}

ひずみ取り方法は, 線条加熱と冷却法によるもの, 当てビシによる打ち出しによるものを併用した。

加熱法としては加熱バーナー, TIG アーク, 誘導 電流があり, 冷却法としては水, 冷却空気がある. TIG アーク誘導電流によるものは入熱コントロー ルが可能であり, 冷却法は, 冷却空気によるものが 作業環境向上のため有効と考えられる.

\section{4 実験概要}

1991 年 10 月から 12 月にかけて, 速力試験を瀬戸 内海の家島沖及び横浜沖で, 操縦性試験を東京湾で, 耐航性試験を相模灘で行った, 速力試験・操縦性試 験の結果は良好であり, 事前の推定值ともよく一致 した. 耐航性試験においては, 実海象下における船 体運動, 波浪荷重, 衝撃荷重及び船体構造応答等の 諸特性を把握するために, 以下の諸項目を船速及び 波との出会い角度を変化させて計測をおこなった。

(1) 波浪中での船体運動, 速力, プロペラ回転数

（2）双胴連結部及び DSB 部にかかる衝撃圧力, 船体構造ひずみ

（3）定点波高

SSTH 実験艇の双胴間衝撃圧力の推定值との比 較を表 1 に示す. 計測位置は操舵室付近である.こ の計測結果は KARMAN の式 ${ }^{2)} よ り$ 推定した結 果とほほ一致している11.

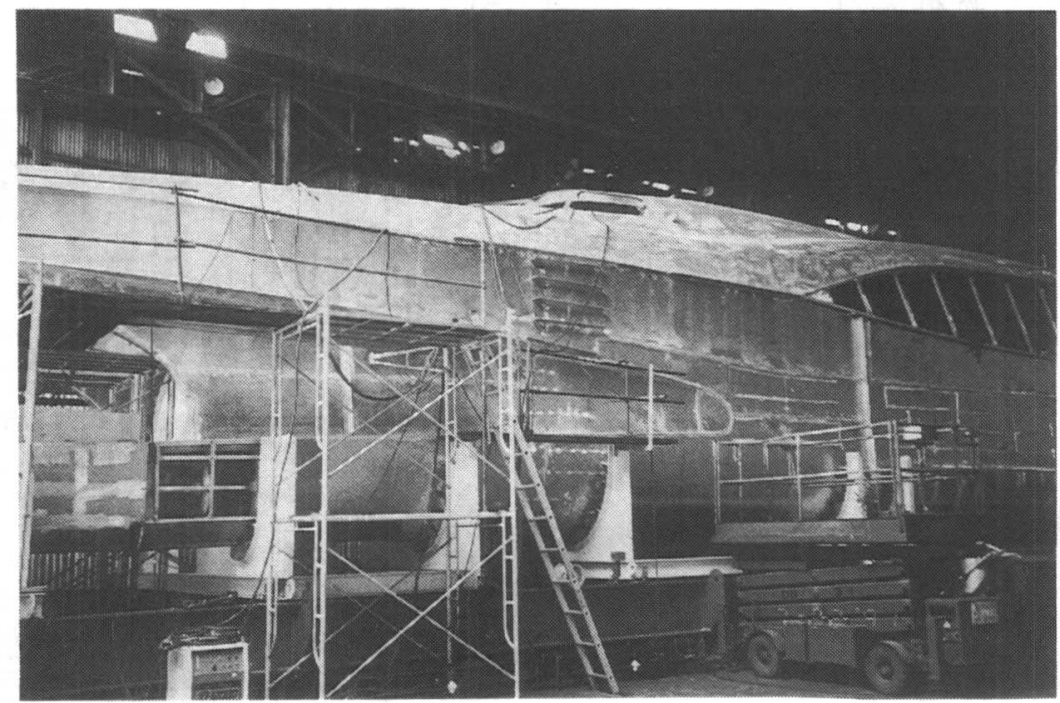

図 2 SSTH 30 建造の様子 
表 1 双胴デッキの衝撃圧 (単位： $\mathrm{kPa}$ )

\begin{tabular}{|c|c|c|}
\hline 種別 & F R. 20 & F R. 21 \\
\hline 予測值 & 147 & 203 \\
\hline 計溂俥 & 150 & 163 \\
\hline
\end{tabular}

\section{SSTH 船型の高速フェリーの設計の一例}

\subsection{SSTH 90}

SSTH のコンセプトはその高い経済性と良好な 乗り心地から, 車両及び旅客用の高速フェリーに適 している．また，排水量型であるゆえに，50 m から $200 \mathrm{~m}$ クラスの高速フェリーにまで容易にスケール アップできる.

設計の一例として, 全長約 $90 \mathrm{~m}$ の 80 台積み高速 カーフェリーの完成予想図を図 3 に示す。本船は, 上甲板に約 80 台の乗用車用の車両甲板を, 2 層目甲 板には 400 席の乗客スペースを配置した 2 層甲板の 双胴船である。

船体材質はアルミ合金であり，主機関は高速 ディーゼル各二機を片胴内に配置している. 推進器 はウォータージェットを採用している.

この $90 \mathrm{~m}$ 型高速カーフェリーの主要目を以下に 示す.

全長 $\quad 92.4 \mathrm{~m}$

幅（型） $19.4 \mathrm{~m}$

深さ (型) $5.6 \mathrm{~m}$

総トン数 約 2,300 トン

旅客定員 400 人

乗用車約 80 台

最大速力 約 40 ノット 主機関＼cjkstart高速ディーゼル 4 基

最大約 $5150 \mathrm{KW} \times 4$

推進器 ウオータージェット 2 基

航続距離 約 200 海里

船体材質 アルミ合金

\section{2 構造設計}

アルミニウム合金製の高速船の大型化には近年目 ざましいものがあり,例えば英仏海峡には長さ $74 \mathrm{~m}$ のウエーブピアサー型カーフェリーが就航してい る.これらの大型高速船に対応すべく新しいルール がノルウェー船級協会, ロイド船級協会などから発 行されている.

国内においても「軽構造船暫定基準」や「軽構造 船基準 (案)」などがあるが，より大型の高速船に対 応する基準を(社) 日本造船研究協会において現在検 討中である。

これらの新しいルールは, それぞれの高速船の運 航条件に基づいた設計となっている.SSTH 90 にお いてもこれらのルールの考え方に従い, 運航条件に 見合った荷重を設定し, 解析に基づいた構造設計を 行っている。

\section{2 .1 荷重設計及び構造応答}

小型船では外板の板厚は衝撃荷重などの局所荷重 による強度が支配的であるが，船体の大型化に伴い 縦強度などの全体強度の重要度が高まってくる，ま た，双胴船ではスプリットフォースやピッチコネク ティングモーメントなどの荷重も重要となる.

SSTH 90 では, これらの波浪荷重を解析的に求め 設計荷重を設定した。一例として, 綐曲げモーメン トおよびスプリットフォースの応答関数を図 4 , 図 5 に示す.横軸は波長 $\lambda$ を船長 L で無次元化した值て

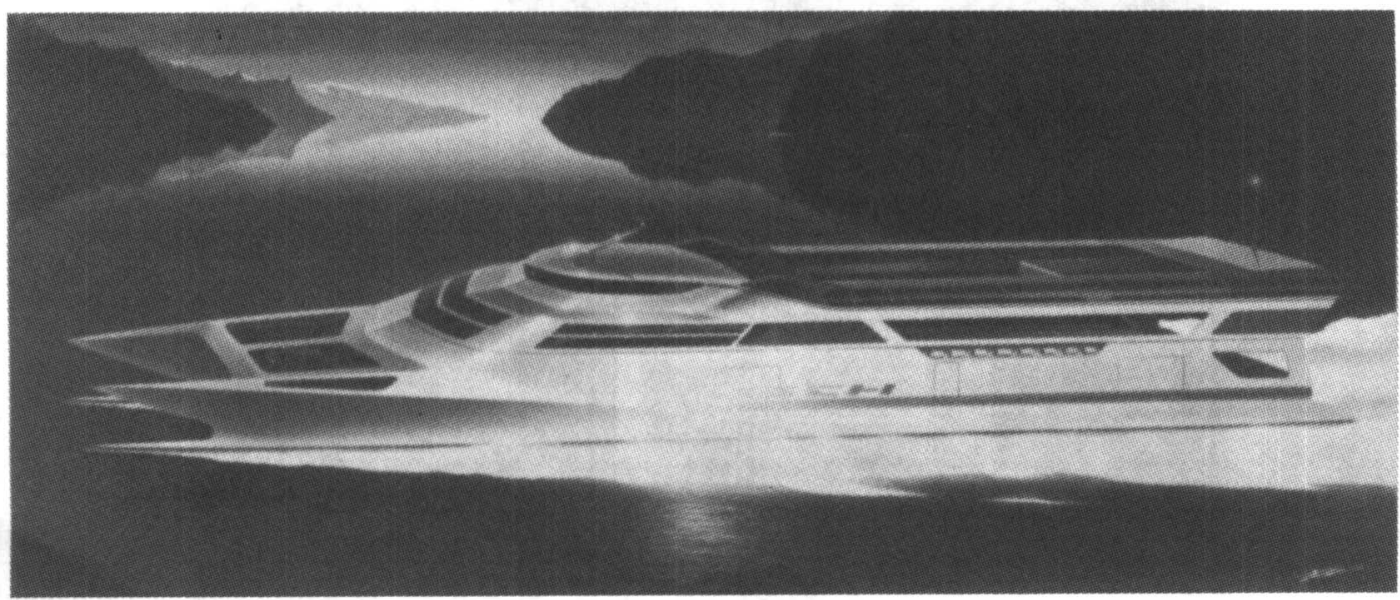

図 3 SSTH 90 完成予想図 


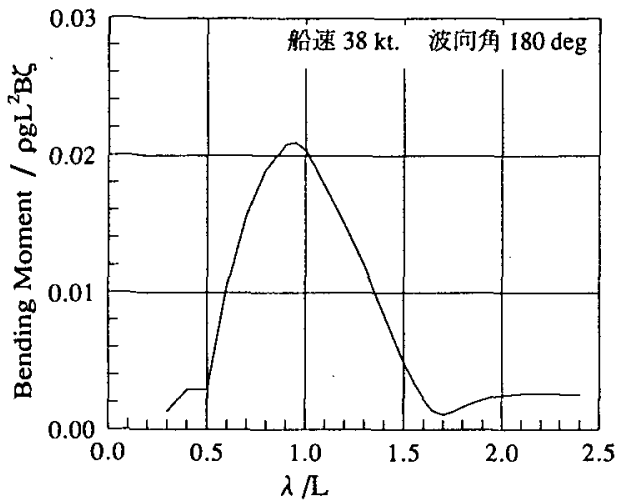

图4船体中央における繸曲げモーメント

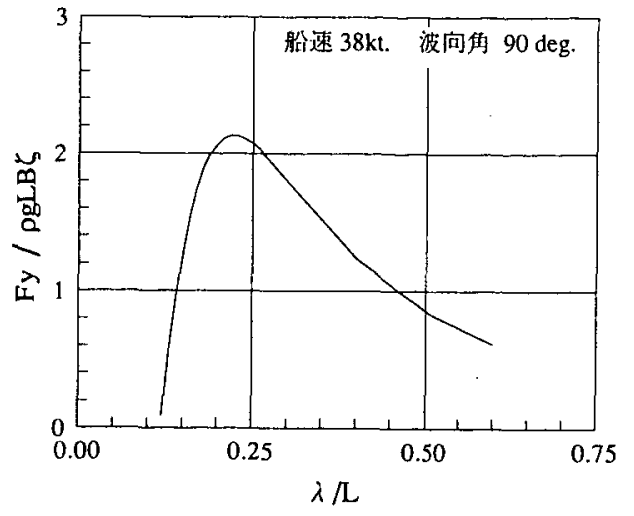

図 5 スプリットフォース

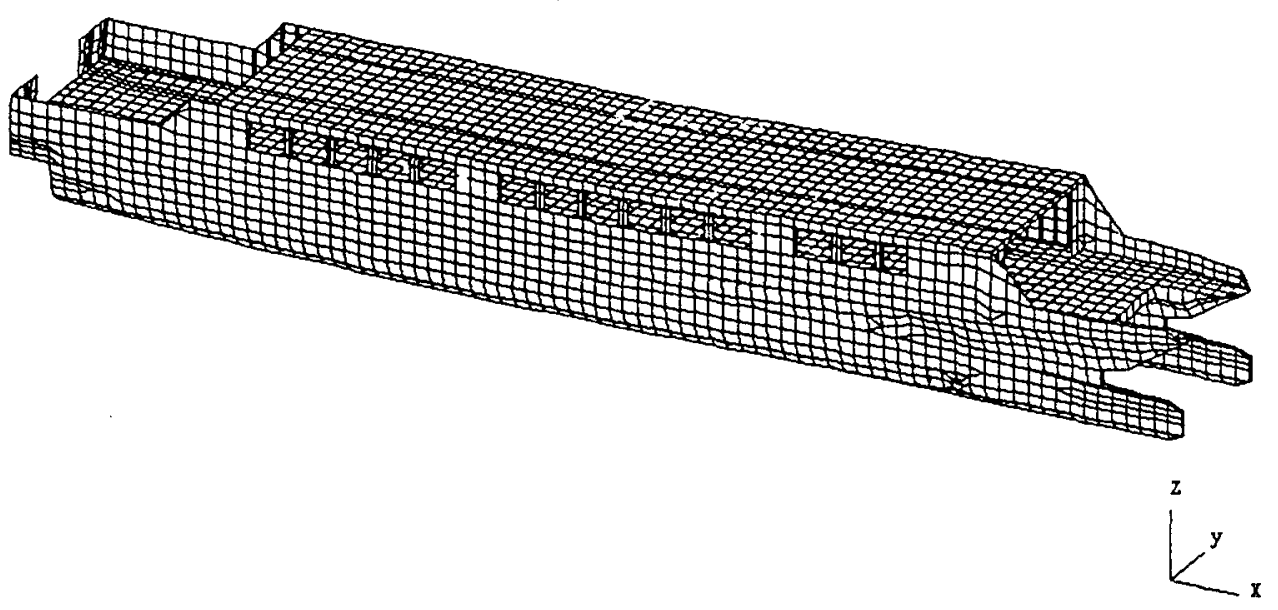

図 6 SSTH 90 FEM モデル

あり，緃軸はそれぞれの荷重を海水の比重 $\rho g$, 船長 L，船幅 Bおよび波高 $\zeta て ゙$ 無次元化した值である。 縦曲げモーメントは向い波中，スプリットフォース は横波中の船速 38 ノットの場合の計算結果である. これらの波浪荷重の応答関数と，航路や運航条件か ら決まる波浪条件を基に設計荷重を設定している。 構造忘答については，全体 FEM モデルを作成し，解 析を実施している。これを図 6 に示す。

\section{6. 結 言}

本報告においては，SSTH の開発の経緯を設計， 加工の面から述べた。

高速船型と言えば，滑走型，半滑走型，水中翼型 及び空気圧力型が直ちに連想されるが，本研究開発 では，船舶の高速化の常識の範囲外にあった排水量 型の船型を超細長双胴化することにより，優れた高
速燃費性能, 而航性能を備えた高速フェリーの出現 の可能ならしめたことに最大の特徴を有する.

最近, 高速船の開発の一環として実験艇を建造し， 実海域試験を行う例が多い，本開発におろても実験 艇を建造したことによって，設計・製造の両面にお いて数多くの知見を得られた。

最後に，本研究の当初加ら研究と開発の全般にわ たってご指導とご協力を頂いた東京大学船舶海洋工 学科宮田秀明教授に深く感謝申し上げます。

\section{参考 文 献}

1）野上 浩, 㴖口純敏：“超細最双胴型高速フェリー とその $30 \mathrm{~m}$ 実験艇による実海域実験”，石川島播 磨技報第 32 巻第 4 号, 1992

2) T. Vor. Karaman, "The Impast on Seaplane Floats During Landing",: NASA TN321, 1921 